Ymke de Groot ging na welke steun bewoners in haar woonzorgcentrum van zorgmedewerkers, familieleden en overige sociale contacten ervaarden tijdens de COVID-19-crisis.

\title{
De ervaren steun van ouderen tijdens de lockdown
}

\section{Praktijkprobleem}

Als gevolg van de 'intelligente lockdown' moesten verpleeg- en verzorgingshuizen op 20 maart 2020 op slot. Hierdoor mochten de circa 120.000 bewoners van verzorgings- en verpleeghuizen in Nederland hun zorginstelling niet verlaten en geen bezoek ontvangen. Dit had als consequentie dat de COVID-19 crisis voor ouderen niet alleen een gezondheidsrisico werd, maar ook een sociale ramp. Sociale isolatie kan negatieve effecten hebben op het welbevinden. Ouderen hebben over het algemeen een zwak immuunsysteem. Dat wordt nog meer verzwakt als daar gevoelens van eenzaamheid bijkomen. Dit heeft tot gevolg dat sociale isolatie bij ouderen, oftewel een gebrek aan sociale, praktische of emotionele steun, de kans op overlijden verhoogt. Het is dan ook van belang de ervaren steun van ouderen ten tijde van de COVID-19-crisis nader te onderzoeken.

\section{Methode}

Om de onderzoeksvraag te beantwoorden, zijn tien semigestructureerde face-to-face-interviews afgenomen bij acht individuele bewoners en twee echtparen wonend in een woonzorgcentrum. De duur van de interviews was gemiddeld dertig minuten. Voor het interpreteren van de uit interviews verkregen data is gebruikgemaakt van een thematische analyse met Atlas.ti.

\section{Resultaten}

Uit de data zijn drie belangrijke hoofdthema's naar voren gekomen: gebrek aan sociale steun, moeite met onderhoud sociale contacten en pampering. De meeste respondenten gaven aan praktische en emotionele steun te ontvangen van naasten, maar een gebrek aan sociale steun te ervaren. Dit heeft een eenzaam gevoel tot gevolg. De respondenten nemen echter weinig initiatief om uit het sociale isolement te treden. Zo nemen bewoners nauwelijks initiatief om contacten met hun naasten te onderhouden. De oorzaak is dat ze weinig te vertellen hebben als gevolg van een gebrek aan sociale steun. Wat daarnaast opvalt, is dat bewoners tijdens de coronacrisis als het ware 'gepamperd' worden door zorgmedewerkers en naasten. Zo zei een bewoner: 'Ik zit hier, ik mag het niet zeggen, maar in een zorghotel. Ik krijg alles op m'n bordje'. Tijdens de coronacrisis worden de bewoners veel handelingen en activiteiten ontnomen. Zo mogen bewoners niet zelf hun post uit de brieven-
YMKE DE GROOT Leeftijd: 21 Is: ondersteunende hulp VVT-organisatie Surplus, locatie 'De Zeven

Schakels' in Zevenbergen Opleiding: Gezondheidswetenschappen Erasmus School of Health Policy \& Management, Rotterdam bus halen en kunnen ze zelf geen boodschappen meer doen. De mogelijkheid tot het ondernemen van activiteiten en dus het ervaren van sociale steun wordt belemmerd door pampering.

\section{Toepassing in de praktijk}

Zorgmedewerkers en familieleden moeten de bewoners minder 'pamperen'. Het is belangrijk dat zij hen in staat stellen om te gaan met COVID-richtlijnen. Bewoners zijn nu afwachtend totdat ze iets aangeboden krijgen, waardoor ze zelf minder initiatief nemen tot activiteiten. Zorginstellingen moeten 'zelfmanagement' stimuleren, zodat de bewoners zelf in the lead gezet worden, meer controle over hun eigen leven krijgen en activiteiten omhanden hebben. Hierdoor zullen bewoners ook sociale steun ervaren en uit het sociale isolement kunnen treden. Het gevolg hiervan is dat eenzame gevoelens gereduceerd worden en de negatieve effecten hiervan op het welbevinden van ouderen voorkomen kunnen worden. 